\title{
IMPLEMENTATION POSSIBILITIES FOR THE CONCEPT OF MANAGEMENT ACCOUNTING IN THE REPUBLIC OF MACEDONIA
}

\author{
Blagica Koleva ${ }^{1}$ \\ University “Goce Delchev" - Shtip, R.Macedonia \\ Olivera Gjorgjieva-Trajkovska \\ University "Goce Delchev" - Shtip, R.Macedonia \\ Vesna Georgieva-Svrtinov ${ }^{3}$ \\ University "Ss. Cyril and Methodius" \\ Institute of Economy-Skopje R.Macedonia
}

\begin{abstract}
The actual business conditions which are featured with great number of changes in the social and political system in the Republic of Macedonia have their impact in all the spheres of the social life, including the accounting-management profession. The fact that "the modern management is not compatible with obsolete accounting" is very often emphasized. As it is natural, the management accounting should be adjusted to the management needs.

Starting with this statement, the research subject of this study will be the process of implementation and efficient functioning of the management accounting in the companies and organizations in the Republic of Macedonia, taking into consideration their impact on the success of the companies and their functioning. On the other hand, the scientific-empirical goal, on the basis of empirical research, is completely focused on the ways of implementing of the management accounting as one kind of contemporary approach of the managers in the organizations by the means of high management, undercovering completely the possibilities for efficient implementation and application of the management accounting concept in the Macedonian organizations.
\end{abstract}

Key words: accounting, financial reports, company, management, management accounting, financial accounting.

\section{INTRODUCTION}

Nowdays, due to the growth and development of the economic activities in Macedonia, there is a great need for following up and evidenting of the course of the working processes, in the same time analyzing the results from the functioning-developing the accounting activity. However, the costs as economic and accounting category are present in all the spheres of the social framework. The historical data point to the fact that they were present even in the earliest forms of human existence and working. From the beginning, the human decision was

\footnotetext{
${ }^{1}$ blagica.koleva@ugd.edu.mk

2 olivera.trajkovska@ugd.edu.mk

3 vesna.svrtinov@ek-inst.ukim.edu.mk
} 
based on the costs which are identified by the means of rational spending of means and labor. The prime goal of existing and functioning of the most of the companies is increasing of the financial result by fulfilling of the payment deadline obligations and payment related to the demand within the maturity deadline. The realization of this goal represents existence of data for the working process, how is it going, is it prospering, regressing or stagnating as well as the other data necessary for business decision-making. The goal of the management accounting in the companies is to offer assistance to the accounting in the companies, with an aim to realize its purposes which are sat in terms of the decisionmaking, combining the information related to the costs with the other non-cost information, including the subjective evaluations for the business activities and their non-financial effects. The management accounting is a sub-system of the accounting information system, which aims to assist the accounting in the company for goals' realization and deals with collecting of business and financial data, their preparation and representation as well as with interpretation of the accounting reports exceptionally for the needs of the companies' accounting in Macedonia and all around the world.

\section{THE ROLE OF MANAGEMENT ACCOUNTING IN THE PRESENTATION OF INFORMATION TO THE MANAGEMENT}

The management accounting has first appeared in the time of the industrial revolution as an instrument for measuring and managing of the expending of the resources and the productivity on the operative level of the company. Its prime focus was sat on providing the necessary information for planning and control of the productivity and efficiency of the interior business processes. As a whole, the information from this accounting were indirectly relevant to the demand for optimizing of the costs, the time and the utilization of the means. The management accounting is a process of providing information for the needs of the managers. Namely, this type of accounting is responsible for providing information and it assists the managers in the process of business decision-making for more efficient and effective utilization of the organizational resources. ${ }^{4}$ The literature related to the management accounting points out that this accounting is a knowledge body, understanding of which is necessary for the management success. For

\footnotetext{
${ }^{4}$ Hendrickson, H. (2001). Accounting. In: Encyclopedia of Business and Finance. Eds. Burton Macmillan. USA, p.512.
} 
example, Horngren ${ }^{5}$, considers that the management accounting presents and interprets financial and non-financial information which is of an assistance for the managers to make decisions for the realization of the established organizational goals. After all, the provided information are used by the managers for choosing, communication and implementation of the strategy. They also use the information provided with the management accounting for coordination of the production design, production and marketing decisions. This accounting is information system for support which, at its best, supports the communication, motivation and the evaluation of the performances within the different organizational structures. The management accounting, actually, offers quality information which improve the process of business decisionmaking, assists in the preparation of the strategy and focuses on the efforts related to the improvement of the organizational performances, evaluating the contribution of the separate organizational units towards the improvement of the company as a whole. ${ }^{6}$. Practically, the management accounting is such an accounting concept that appears as a consequence of the intentions of the accountants, by the means of information, to support the management in the management process. Its appearance coincides with the need for wide spectrum of information in the management structures, to which, the traditionally externally and historically oriented financial accounting can not give the adequate response. In time, the management needs for information have become bigger, thus resulting with dynamic development of the management accounting.

\section{THE NEED FOR DEVELOPMENT OF MANAGEMENT ACCOUNTING CONCEPT}

The development of the accounting in our country before the beginning of the $21^{\text {st }}$ century was under strong impact of the developmental intitiatives in the accounting theory and practice in the developed countries and it is very similar with the case of the other countries in transition. However, the radical changes in the last decade of the twentieth century, such as the expressed globalization of the business functioning, the strong pressure from the competition and the new production technologies, put under question many of the activities that were traditionally executed. Namely, many companies started to question

${ }^{5}$ Horngren, Ch., Datar, S., Foster, G. (2006). Cost Accounting: A Managerial Emphasis. 12th ed. Prentice Hall, p. 868.

${ }^{6}$ Kaplan, R., Atkinson, A.(1998). Advanced Management Accounting. 3rd ed. Prentice Hall, p.798.

Vol. 18, бpoj 1/2016, cmp. 85-99 
their business practice. As a consequence, there were significant changes of the business systems themselves. Having on mind the fact that the business subject is live organism whose segments are mutually tightly related, interlaced and complement each other, the changes in any segment induce changes in the other segments as well. In this way, the changes in the business subjects cause changes in the philosophy of the management as well. In this context, it is necessary to mention the changes in the field of the management which are featured with contemporary approaches, methods, concepts, instruments and techniques which have led to a significant advancing of the practice of the contemporary management. Since the quality of the management process greatly depends on the information support of the accounting information system, its re-designing is necessary. However, the advancing of the management, especially of the accounting system in the Macedonian business subjects is greatly behind the world's theoretic achievements, and especially behind the practical experiences. Starting with the fact that the needs of the operative management condition sine qua non and the competition advanced achievements in the contemporary business environment, it is necessary to adjust the accounting to these requirements with same time maintenance of the role of integrator of the business activities and a guardian of the solely business tissue of the business subject in terms of managing according to the cholistic principle. ${ }^{7}$ Thereby, the needs of the management for information become bigger, although they are very often incomplete, untimely and unadequate. Due to these reasons, the need accountants themselves to reassess the value of the information they get by the existing accounting systems for the needs of the management becomes more than necessity. Actually, the basic characteristic of the existing accounting systems is that they are in the function of providing information for the needs of the external financial reporting and they have been applied in a period when the production technology had high working intensity with dominant participation of the direct costs in the structure of the total costs which is totally different from the contemporary working conditions of the contemporary businesses which are featured with dynamics, turbulence and uncertainity. Thus, it happens often that the provided information from such systems are completely unusable or can lead the management in the wrong direction.

Based on the above mentioned, it can be concluded that the present system of management accounting hasn't been ready for the

\footnotetext{
${ }^{7}$ Blagoje Novicevic, (2012). Convergation of the information demands of the accounting and the operative management, $43^{\text {rd }}$ Symposium Economic / Financial crisis and the accounting system, Zlatibor, p.254.
} 
changes of the business environment which happened in the last decades. The concequences of this are as follows: ${ }^{8}$

$>$ The information from the management accounting directed by the procedures and the cycles for financial reporting are untimely and dislocated as to have importance for the management decisions related to the planning and control processes,

$>$ The reports of the management accounting assist very little for the effort of the executive managers to reduce the costs and increase the productivity. These reports are actually difficult to understand for the managers because they are very little related to the real technological processes under their direct competence. In this way, their interpretation takes a lot of the managers' valuable time,

$>$ The present system of the management accounting doesn't provide reliable information for the production costs. Namely, the traditional accounting procedures for covering of the costs allocate them by applying simple methods based on the direct labor, thereby not taking into consideration the costs for bad quality, repair of the equipment, costs for materials deficit etc. However, if we take into consideration the fact that the costs of the direct labor today have very low participation in the total production costs $(8-12 \%)$, it can be concluded that the provided information for the price per unit product lead the management in a wrong direction,

$>$ The managers are traditionally used to monthly reporting. In such circumstances, the financial accounting is ready to report a big part of the cash outflow as expenses in that period, although they will be expected to be beneficial in the future. A typical example for this are the preventive maintenance of the equipment, improving of the production, costs for introducing new products, training for the employees, long-term positioning on the market etc.

In this way, the significant falling behind of the accounting practice in terms of the management one, implies serious requirements for advancing of the accounting practice. Being aware of this, the accountants, step by step, have started to re-design the obsolete accounting systems and create new ones in order to be able to provide the needed information which have key impact on the efficency of the business decision-making in the management teams. In this way, the management accounting becomes significant component for achieving of a competitive advantage.

\footnotetext{
${ }^{8}$ R.Cooper, R.Caplan,(1988). Measure Cost Right:Make the Right Decision, Harvard Business Review, p.96-99
} 


\section{EMPIRICAL APPROACH TOWARDS THE RESEARCH}

In the frames of the research implemented in the study, the qualitative analysis is mostly applied, within which, with an aim to implement the effective hypotetic-deductive-inductive conclusion, the quantitative method of research is applied. With an aim to realize the upfront sat empirical goals within the subject-matter of the study, the implemented methods are based on the objectivity, validity as well as on the efficiency of the processing of the primary and secondary data provided with the qualitative and the quantitative research. The primary data which are processed are provided by the means of utilization of the domestic and foreign literature on the subject-matter, while the secondary data are additionally processed by inclusion of targeted examineesmanagers and accountants of certain number of companies in the Republic of Macedonia.The qualitative research uses a comparative approach and a technique of a short questionnaire of open type without suggesting the answers where the personal data of the examinees are discretly respresented with a goal to motivate valid answers. With an aim to represent the hypothetical frame of the given research as well as its confirmation and negation after the qualitative review of the analyzed subject-matter, it is necessary to give theoretic background in the frame of which the definition and the core of the subject-matter itself are represented.

\subsection{IMPLEMENTATION PHASES AND DEVELOPMENT OF THE MANAGEMENT ACCOINTING IN THE MACEDONIAN COMPANIES}

The management accounting is an activity which should be implemented in the sole process of managing in all the companies in the Republic of Macedonia. A part of the organizational activities should cover management accounting, where in the Macedonian companies there are four development stages of implementation of the management accounting as follows ${ }^{9}$ :

I stage - the focus are the factors for the working process and the financialcontrol, by using of budgeting and technology of costs accounting

II stage -in the last years, the focus is on the preparation of information for the accounting, planning and control, by using of the

\footnotetext{
${ }^{9}$ Martin, J. R. (1990). Management Accounting: Concepts, Techniques \& Controversial Issues, Cambridge: Cambridge publishers, London. p.37
} 
technology as well as the decisions for analysis and the responsibility which should be a feature of the accounting in the company

III stage - in this period, the attention should have already been focused on the reduction of utilization of the resources in the business processes, by using business analyses and technology of costs management in the companies

$I V$ stage - the attention here is focused on the realization and creation of values by effective using of the company's resources.

According to this, the management accounting in the companies should mostly refer to the future activities and to the analysis of their execution in the further working of each company. The high degree of flexibility should be implemented mostly in the preparation of the reportsthe structure of the reports should be prepared by the management itself.

Therefore, the phases of implementation and development of the management accounting can be shown graphically in the figure nr. 1 below.

Figure 1.: Graph - phases in the implementation and the development of the managementl accounting in the Macedonian companies

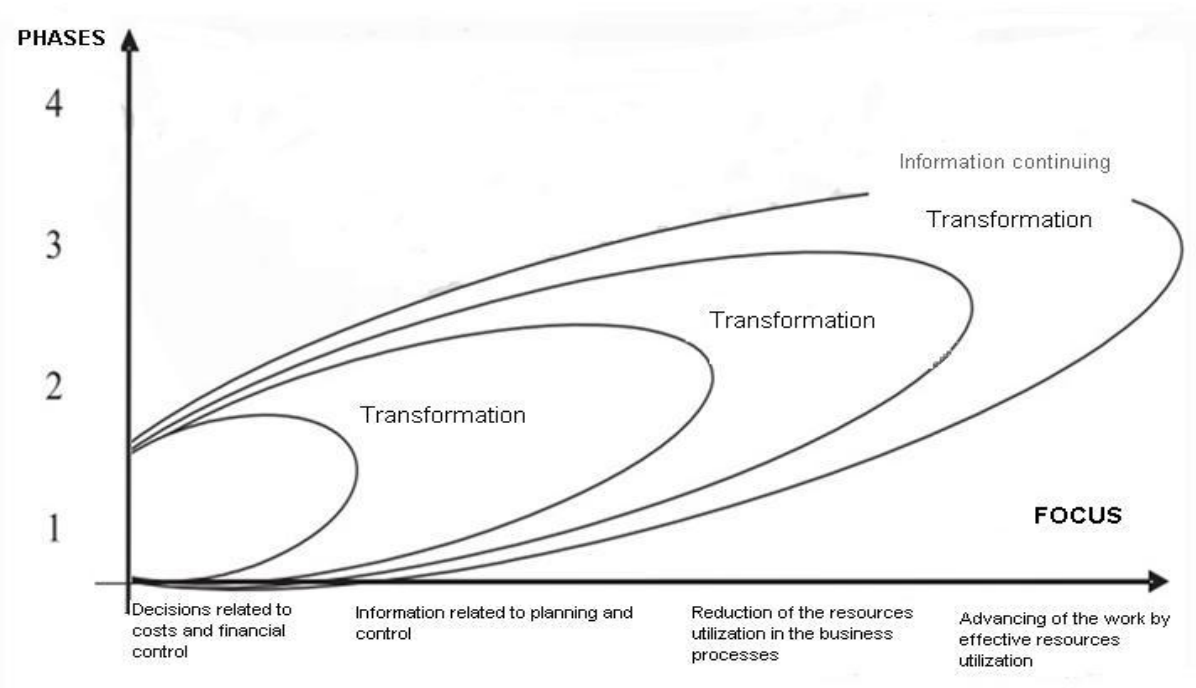

Taking into consideration the phases in the implementation and the development of the management accounting in the Macedonian companies, it can be concluded that starting from its first appearance until today, it has kept its core function -meeting the information needs of the 
management structures. A great number of researches confirm that there is a tight relation between the efficient management and the quality informing. ${ }^{10}$ The greatest part of the needed information are provided by the management accounting which has a crucial role in the efficient management process. Actually, the sole management accounting is an integral part of the management process.

\subsection{IDENTIFYING OF THE POSSIBILITIES AND THE BARRIERS FOR IMPLEMENTATION OF THE STRATEGIC TECHNIQUES OF THE MANAGEMENT ACCOUNTING IN THE REPUBLIC OF MACEDONIA}

Strategically oriented management accounting functions as a system for support of the business decision-making of the managers in the companies. The business decisions-makers in the analysis, i.e. in the auditing of the present financial situation, being basic for the defining of the strategic directions, must use accounting information in the context of a few key elements as follows ${ }^{11}$ :

$>$ Companies`mission

$>$ Strategic goals

$>$ Operative goals

$>$ Operative strategies

$>$ Performance measuring

In this context, there are few symptoms and factors of failure which have a strong influence on the financial performance in the companies as follows ${ }^{12}$ :

* Financial accounting

* Exaggerated optimism

* Errors

* Shortages and irregularities in the working

* External signs

However, in most of the cases, the bad factors and signs which show inadequate planning in a company originate from low profitability, high indebtedness, together with the problems related to the cash flows represented by the lack of ability to fulfill the financial tasks and settle the obligations or find a working capital for financing of the changes. According to this, it can be surely seen that the management accounting is

\footnotetext{
${ }^{10}$ Mohsen Attaran, (2004). Information \& Management, Amsterdam, p 585-596.

${ }^{11}$ Jackson, S. \& Sawyers, R., (2002) Managerial Accounting: A Focus on Decision Making, Cincinnati, Ohio: South-Western/Thomson Learning. p.84

${ }^{12}$ Martin, J. R. (1990) Management Accounting: Concepts, Techniques \& Controversial Issues, Cambridge: Cambridge publishers, p.11
} 
implemented in the given companies as one type of contemporary approach of organizing and strategic planning of the costs, managing the future business decisions, analyzing and anticipating the financial situation in the companies where all these functions are responsibility of the company`s management. Therefore, with an aim to have an efficient strategic functioning of the company, the factor of adequate implementation of the management accounting in a company is of a huge significance-it consists of few tasks and depends on more factors.

The key areas for application of the management accounting in the public sector in Macedonia cover few tasks as follows ${ }^{13}$ :

* Planning and preparation of a financial plan, i.e. calculation

* Control and reduction of the costs

* Determining of the prices and fees

* Evaluation of the programs and measuring of the working result

* Difference in the choices and the economic decisions

According to this, with an aim to consider the possibilities and the areas within which the management accounting can be implemented as well as to consider the influence and the effect of a well-implemented and developed management accounting on the work of the company, the organization in the Republic of Macedonia, the below implemented research is executed. In the given research, the qualitative analysis is implemented by the means of which examinees are chosen in the frames of the targeted managers of few bigger companies in Macedonia, including the Quatro company, Serpent as well as MS-City companies. These companies are chosen with a goal to cover more industries as well as companies with different sizes and with different scope of work. Quatro is regarded as a big corporation, i.e. a company from the sector of big companies in Macedonia, Serpent is a medium-sized company, i.e. from the sector of medium-sized companies and the MS-City company belongs to the sector of small companies in the Republic of Macedonia. These companies have different functions, Quatro functioning in the field of production and sale, Serpent is focused on the sale, being part of the services sector and MS-City belongs to the production and services sector. These differences enable bigger scope of the given research on which base the hypothetic-deductive conclusion can be made on the basis of primary and secondary data from the research. The center of the research is the impact as well as the possibilities for an effective implementation of the management accounting in these companies.

${ }^{13}$ Collier, P. M. (2003). Accounting for Managers: Interpreting Accounting Information for Decision Making, London, p. 104.

Vol. 18, бpoj 1/2016, cmp. 85-99 
According to this, in terms of the financial working, functioning within the costs management process, within the implementation of the management accounting in the companies, the managers noticed few improvements in the companies; the responses are implemented in the graph nr. 1 below.

\section{Graph 1.: Areas of improvement due to the effective implementation of the management accounting according to the private experience of the managers}

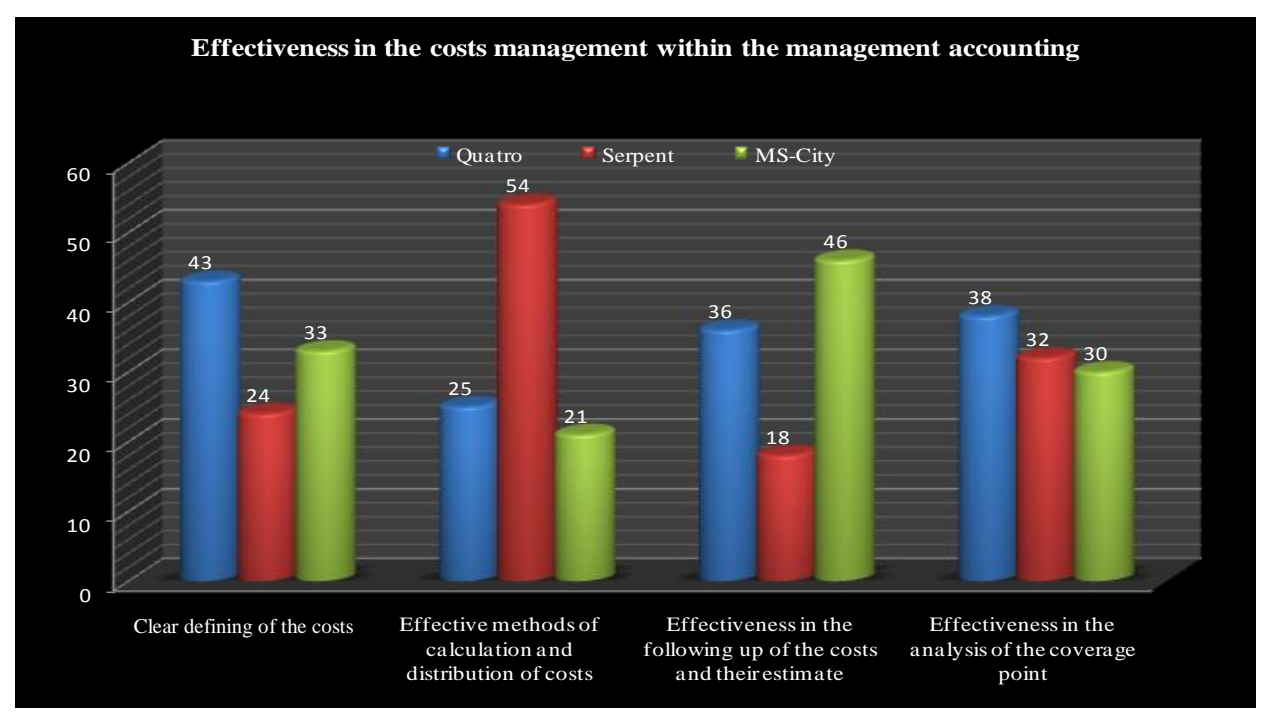

Source: Author's calculations, 2015

Each of these three companies selected all its managers from the sectors they have. All managers selected began to make their decisions according the information obtained from accounting.

In this research were included 7 managers from Quatro, 5 managers from Serpent and 3 from MS-City (one manager from each sector). So, making their decisions according information taken from accounting their success was different in different fields.

For example: Quatro increased its level of clear defining of the costs for $43 \%$, Serpent for $24 \%$ and MS-City for $33 \%$.

Other improvement they made in the field of the methods of calculation and distribution of costs: Quatro increased its effectiveness in this area for $25 \%$, Serpent for $54 \%$ and MS-City for $21 \%$.

Companies also increased their efficiency in the field of following up of the costs and their evaluation (Quatro 36\%, Serpent 18\% and MSCity 46\%). 
And the last field where they had improvement is the field of efficacy in the analysis of the coverage point where they increased efficacy: Quatro for 38\%, Serpent 32\% and MS-City 30\%.

Considering the graph 1 above, it can be noticed that each company has a certain level of impacts and activities which are significantly improved with the implementation of the management accounting. Therefore, in respect of the clear defining of the costs being followed up in the organization, Quatro has recorded the biggest improvement in this area (43\%), while Serpent has had the least. On the other hand, the managers of the company Serpent have recorded the biggest impact and improvement by finding out and by applying of far more effective methods of calculation and distribution of the costs in their work. In terms of the managers of MS-City, the biggest improvement by implementing of the management accounting in their company within the costs management process has been recorded in respect of the improved and more efficient functioning in the process of following up of the costs and their accurate evaluation of the present situation as well as in respect of the future anticipating and analyzing as well. This is normal and significantly useful for the small companies, of course. However, these improvements and the effective functioning in of the managing of the obligations, costs (in the given case the companies), are accentuated after the effective implementation of the management accounting. However, it is a fact that the management accounting in Macedonia is still a significantly modern management tool for the management in the companies and organizations on the Macedonian market, i.e. region. Therefore, it is extremely significant to identify the area, i.e. the possibilities that the companies possess in order to implement and apply efficiently the concept of management accounting. These possibilities appear in the different areas of functioning of the companies. In order to be able to recognize these possibilities, the qualitative - quantitative research is applied together with a case analysis which refers to few insignificant, smaller companies in Skopje. What is crucial for these companies if the fact that they still haven't had implemented the concept of management accounting, despite the implementation of the management of costs, obligations, property as well as financial accounting and auditing. Therefore, on the basis of an implemented analysis and the method of synthesis and comparation, several possibilities that the companies possess in terms of an efficient application of the concept of management accounting were identified (table-graph 2). 
Table Graph 2.: Possibilities for application of the management accounting in the companies in the Republic of Macedonia

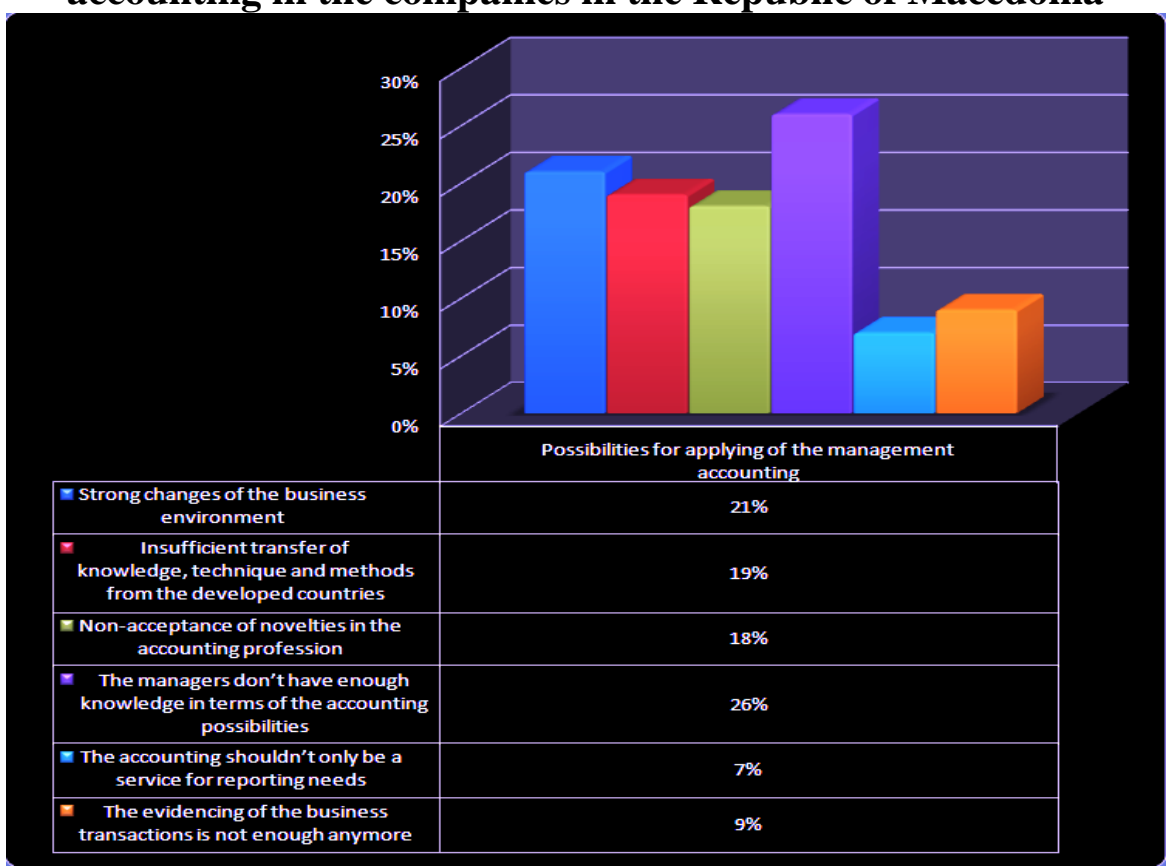

Source: Author's calculations, 2015

Taking into consideration the quantitative-qualitative research implemented on the basis of an application of the analytical approach for studying of the primary and secondary data provided from the research area, statistical data pointing to significantly surprising facts were obtained. As it can be noticed from the Graph nr. 2, there are more possibilities for implementing of the concept of management accounting in the companies in Macedonia, out of which certain have bigger impact on the instigating of this contemporary concept, while the others have lower impact. According to the managers of the above mentioned companies, these possibilities have different impacts on each of them, yet, all of them have something in common-more or less, they initiate and instigate implementation of the concept of management accounting in the companies. As it can be seen, the fact that the managers do not have enough knowledge about the possibilities and the advantages of the accounting and its impact on the company's functioning in all the activity areas, although being negative by nature, however, is the biggest instigating factor for implementing of the management concept of accounting in the companies (26\% of the managers choose this possibility as the most adequate). Anyhow, the impacts of the strong changes wich have been happening in the business environment is also a possibility for 
implementing of the concept of management accounting (21\%). Besides this, there is still the possibility, despite the insufficient transfer of knowledge and techniques from the developed countries, to have the space and the need for implementing of the management accounting for several companies (19\%). The managers and the accountants in the companies have also mentioned the non-acceptance of novelties from the field of accounting by the biggest number of managers from the rest of the companies in this respect (18\%). Several accountants pointed out that the accounting shouldn't be an evidenting service only (7\%) as well as that it isn't enough anymore to apply the limited approach of the limited, traditional accounting techniques for analysis of the costs and company's functioning in certain area (9\%).

\section{CONCLUSION}

The accounting reforms in the Republic of Macedonia request bigger changes in the approach of management of the accounting tools, emphasizing the linkage of the strategic goals and the accounting tools. The management in the public and the private sector is always responsible not only for the planned costs execution, but for the achieved results, i.e. realization of the planned and programmed goals as well. It is impossible without quality financial-information system which includes implementation of the costs management as well as management accounting. Exactly in this context, this study, with its content and research, contributes for the theoretical frame and the practical solution in terms of the possibility for applying of the methods and techniques of the management accounting as well as of the costs management for the processes in certain activities of the companies in Macedonia. The directions identified with this study point to the key possibilities and areas where an effective implementation of the management accounting can be realized. On the basis of the above mentioned and implemented researches and the secondary data obtained, it can be surely concluded that the most present possibilities in the frames of which the management accounting can be effectively implemented are the insufficient transfer of knowledge from the developed countries, the insufficient knowledge of the managers of the accounting possibilities, such as the fact that the accounting, as the most of the managers have already claimed themselves, taking into consideration the multiple changes of the business climate in Macedonia, is not anymore enough for evidenting of the business transactions and recording of the results only. It is a fact that nowdays the management and the accountants themselves must be more involved in

Vol. 18, бpoj 1/2016, cmp. 85-99 
the running of the business activities and in the costs management in the companies in order to have effective functioning in the given areas.

\section{REFFERENT LITERATURE}

1. Bhimani A., Gosselin M., A. (2004). Cross-national investigation of factors affects $A B C$ implementation, Working paper, Canada.

2. Blagoje Novicevic, (2012). Convergation of the information demands of the accounting and the operative management, $43^{\text {rd }}$ Symposium Economic / Financial crisis and the accounting system, Zlatibor. p.254.

3. Collier, P. M. (2003). Accounting for Managers: Interpreting Accounting Information for Decision Making, London. p.104.

4. Hendrickson, H. (2001) Accounting. In: Encyclopedia of Business and Finance. Eds. Burton Macmillan. USA, p.512.

5. Horngren, Ch., Datar, S., Foster, G. (2006). Cost Accounting: A Managerial Emphasis. 12th ed. Prentice Hall. p. 868.

6. Jackson, S. \& Sawyers, R., (2002). Managerial Accounting: A Focus on Decision Making, Cincinnati, Ohio: SouthWestern/Thomson Learning. p.84

7. Kaplan, R., Atkinson, A. (1998). Advanced Management Accounting. 3rd ed. Prentice Hall. p.798.

8. Kidane, F. (2012) „Decision Making and the Role of Management Accounting Function- a Review of Empirical Literature”, Radix International Journal of Banking, Finance and Accounting, Ethiopia.

9. Magdy Abdel-Kader, Robert Luther, (2008). The impact of firm characteristics on management accounting practices: A UK based empirical analysis, The British Accounting Review 40, London.

10. Martin, J. R. (1990). Management Accounting: Concepts, Techniques \& Controversial Issues, Cambridge: Cambridge publishers. London. p. 11, 37.

11. Mohsen Attaran, (2004). Information \& Management, Amsterdam, p 585-596.

12. R.Cooper, R.Caplan, (1988). Measure Cost Right: Make the Right Decision, Harvard Business Review, p.96-99.

13. Suzanne Byrne, Erle Stower, Paula Torry, (2007). Activity Based Costing Implementation Success in Australia, Preferred Stream: 16 Technology, Quality and Operations Management, Australia.

14. Tomasz Wnuk-Pel, (2010). Changes In Company's Management Accounting Systems: Case Study on Activity-Based Costing 
Implementation possibilities for the concept of management accounting in ...

Implementation and Operation in Medium-Sized Production Company, Eurasian Journal of Business and Economics, Poland.

Рад је примьен: 01.12.2015. Коригована верзија рада пристигла: 09.12.2016. Рад је прихваћен за штампање: 22.02.2016. 
